ACTA THERIOLOGICA

Vol. 26, 5: 83-95, 1981

\title{
The Diet of the Otter and Its Relations with the Feral Mink in Two Areas of Southwest England
}

\author{
Paul CHANIN ${ }^{1}$
}

\begin{abstract}
Chanin P., 1981: The diet of the otter and its relations with the feral mink in two areas of Southwest England. Acta theriol., 26, 5: 83-95 [With 3 Tables \& 3 Figs.].

The results of analysing otter spraints from an eutrophic lake and an oligotrophic stream are described and compared with the results of a study of the mink's diet in the same areas. Differences between the otter's diets in the two areas are explained in terms of availability, and seasonal variation can be linked with changes in fish activity and behaviour. The mink takes a smaller proportion of fish in its diet than the otter, but there is considerable overlap and the mink takes most species of fish eaten by the otter. On the lake, some differences in fish and bird predation can be detected and these may be connected with differences in the hunting behaviour of the predators. Food is abundant in this area and competition for it unlikely. On the river, the pattern of predation of fish by the two species is almost identical, the biomass of fish is low and waterside birds absent, conditions which could lead to competition.

[Dept. Biol. Sci., Univ. of Exeter, Prince of Wales Road, Exeter, Devon].
\end{abstract}

\section{INTRODUCTION}

Although there is a considerable amount of aneedotal information on the diet of the Eurasian otter, Lutra lutra (Linnaeus, 1758) (Harris, 1968), until recently, the only systematic study of its diet in Britain was made by Stephens (1957) on the basis of small collections of faeces (spraints) and guts. Erlinge $(1967,1968,1969)$ has made detailed studies of the otter's diet in eleven areas in Sweden and more recently Webb (1975) and Jenkins, Walker \& McCowan (1979) have reported on studies made in Somerset and Deeside, Scotland respectively.

While collecting scat samples for a study on the diet of feral mink Mustela vison (Schreber, 1777) in Devon, it was found that otter spraints could also be collected in sufficient numbers to make a study worthwhile. In addition, it was felt that the collection of mink and otter scats from the same areas might throw some light on the interactions of the two species in view of the partial overlap in their diets reported in Sweden (Erlinge, 1972) and the fact that it had been suggested that

'1 Dept. Extra Mural Studies, Univ. of Exeter, 5 Walsingham Place, Truro, Cornwall,

[83] 
the presence of mink might have been a factor contributing to the decline of the otter in Britain (Anon, 1969).

The results of the analyses of mink scats are reported in Chanin \& Linn (1980). This paper reports the results of analysing the otter spraints and makes some observations on the relationships between the two species.

\section{STUDY AREAS}

Spraints were collected from two sites, the river Teign and Slapton Ley which are described in detail in Chanin \& Linn (1980). For this reason only brief descriptions are given here.

The river Teign is an oligotrophic moorland stream running off the eastern edge of Dartmoor and then flowing south to the sea, a distance of c. $55 \mathrm{~km}$ from the source. The study area consisted of a $12 \mathrm{~km}$ stretch on the edge of the moor between $140 \mathrm{~m}$ and $70 \mathrm{~m}$ above sea level. The river is mainly fastflowing and boulder strewn but with deep pools at intervals. It is inclined to spate and at one site within the study area, water depth varied from $0.1 \mathrm{~m}$ to $2.4 \mathrm{~m}$ during the course of the study. It is similar in character to the other streams in South Devon frequented by mink and otter, and was the first stream in Devon to be successfully colonised by mink (Chanin, 1976).

Aquatic plants are sparse but the banks are well covered, the river flowing through farmland (mainly pasture), deciduous and coniferous woodland. The invertebrate fauna of the stream is impoverished and the most abundant fish are salmonid species (Salmo salar and migratory and non-migratory S. trutta). Eels (Anguilla anguilla) are present in small numbers and there are also stone loach (Noemacheilus barbatula), minnows (Phoxinus phoxinus) and bullheads (Cottus gobio). Typical woodland and farmland birds and mammals are numerous in the habitats beside the river but waterside birds are scarce.

Slapton Ley is an eutrophic freshwater lagoon on the south coast of Devon. There are two distinct parts known as the Higher and the Lower Ley and these are fed by three small streams, the largest of which is some $10 \mathrm{~km}$ in length.

The Higher Ley is $1250 \mathrm{~m}$ long, between $60 \mathrm{~m}$ and $160 \mathrm{~m}$ wide, up to three metres in depth and covered in reedswamp (Phragmites communis) and floating islands of reed peat supporting willow carr (Salix cinerea). The Lower is $2,250 \mathrm{~m}$ long, $150 \mathrm{~m}$ to $1600 \mathrm{~m}$ wide and up to four metres deep. It consists mainly of upen water fringed by Phragmites. Cover is dense around much of the Ley with bramble (Rubus fruticosus) and blackthorn (Prunus spinosa) thicket in many places. To the west, the land is deciduous woodland, mixed farmland and there are a series of marshes. The eastern side of the Ley consists of a shingle ridge topped with scrub, beyond which is the sea.

Cyprinids (roach Rutilus rutilus and rudd Scardinius eryophthalmus), perch (Perca fluviatilis) and eels are the most common species of fish in the Ley. Pike (Esox lucius) are present in smaller numbers and there are a few trout and sticklebcks (Gasterosteus aculeatus). There is a bird observatory at the Ley reflecting its importance for passage migrants and summer and winter visitors as well as many species of resident birds. Waterfowl, particularly coots (Fulica atra) and mallard (Anas platyrhynchos) are abundant, as are mammals in the woodland and farmland beside the Ley. 


\section{METHODS}

Monthly samples were collected from each site. On the Teign 253 spraints were collected between April 1972 and December 1973, while 389 spraints were collected from Slapton between May 1972 and October 1973.

Spraints were oven dried for $24 \mathrm{hrs}$ and analysed dry. Fish remains were identified by reference to a collection of scales and vertebrae, and fur and feathers with the aid of keys in Day (1966). The approximate size of salmonids eaten was determined by comparison of vertebrae in the scats with those from fish of known length.

The results of faecal analysis can be presented in a number of ways but the three basic methods are frequency of occurrence, percentage volume or percentage weight. The first of these is the quickest and simplest but does not accurateiy reflect the weight of ingested material (Lockie, 1959), tending to overemphasize the importance of items which are taken frequently but in small quantities and under emphasize those which occur infrequently but in large amounts. The other two methods can give more accurate results when correction factors are used but are subject to their own inaccuracies depending on the proportions of undigestible parts in each type of prey. In view of the laborious nature of these methods and the fact that facilities were not available for the determination of correction factors for otters, in this paper percentage frequency of occurrence has been used. Since spraints from the Teign contained fewer items on average (1.40) than those from Slapton (1.59), the results are expressed as a percentage cf the total number of items rather than the number of scats. It must be emphasized however, that the results do not accurately reflect the intake of the otter but give a guide to the relative importance of the various items. A further advantage of using this method of presentation is that it facilitates direct comparison with other workers such as Erlinge $(1967,1969)$ and Webb (1975).

\section{RESULTS}

Results for the whole year are presented in table 1 , and figure 1 shows seasonal variation in the main items of the diet. It will be noted that fish dominate the diet in both areas, constituting from $80 \%$ to $97 \%$ of the items in spraints at various seasons of the year. Significant seasonal variation can be detected ( $\mathrm{chi}^{2}$ test used throughout this paper) in the frequencies of cyprinids, perch, eels and birds at Slapton (all at $P<0.001)$ and of eels on the Teign $(P<0.05)$.

On the river, salmonid fish evidently form the staple diet throughout the year with eels as an important secondary item. Mammals are of minor importance, occurring mainly between October and December when eel predation is lowest. There are two peaks of eel predation by otters on the river and this is similar to predation by mink in the same area (Chanin \& Linn, 1980). The peak in July to September occurs when eels are likely to be most active whereas that in January to March is at a time when they are likely to be inactive and burried in mud (Perrett, 1958). One would expect eel predation to be less in winter, as at 
Slapton Ley: since eels would be more difficult to find. The increase in mammalian predation during October to December is not limited to a single species which suggests a general increase in the amount of time spent hunting on land rather than a response to increased availability in any one species of mammal. Like the mink in this habitat (Chanin \& Linn, 1980), the otter takes a wide range of mammalian prey, six different species of mammal being recorded in only fifteen spraints containing mammal remains.

Table 1

Frequency of each type of prey in the otter's diet, expressed as percentage occurrence.

\begin{tabular}{lcc}
\hline \multicolumn{1}{c}{ Type of prey } & River Teign & Slapton Ley \\
\hline Salmonid & 60.1 & 0.2 \\
Eel & 29.5 & 23.2 \\
Cyprinid & - & 32.1 \\
Pike & - & 6.3 \\
Stickleback & - & 1.5 \\
Perch & 2.3 & - \\
Loach & 91.8 & 91.4 \\
Total Fish & - & 0.7 \\
Ralliform & 0.3 & 3.0 \\
Anseriform & - & 0.2 \\
Passeriform & 0.8 & 3.3 \\
Columbiform & - & 7.1 \\
Unidetifiable & 1.1 & 0.7 \\
Total Bird & 1.7 & - \\
Lagomorph & 0.6 & 0.2 \\
Bank Vole & 0.6 & - \\
Field Vole & 0.3 & - \\
Woodmouse & 0.8 & 1.0 \\
Rat & 0.3 & 0.5 \\
Mustelid & - & - \\
Unidentifiable & 4.2 & 607 \\
Total Mammal & 0.6 & \\
Amphibia & 2.0 & \\
Earthworm & 0.3 & \\
Arthropod & 353 & \\
Total number of & & \\
items found & & \\
\hline
\end{tabular}

A small number of invertebrate remains were found, most were earthworm, one was a large beetle. Amphibia were also of negligible importance, occurring only twice.

Otters at Slapton Ley have a wider choice of fish prey than those on the Teign and all three species which are common in the Ley formed a substantial part of the diet for at least part of the year. Cyprinids were taken most frequently in the colder months of the year (October to March) while eel and perch were more important in the warmer 
half of the year. The figure indicates a marked switch from predation on roach to eel between winter and spring and then smaller changes between seasons for the rest of the year.

The availability of eels may be lower during the winter months (see above) rendering them less liable to predation when other sources of prey are readily available. At this time of year cyprinids are at their
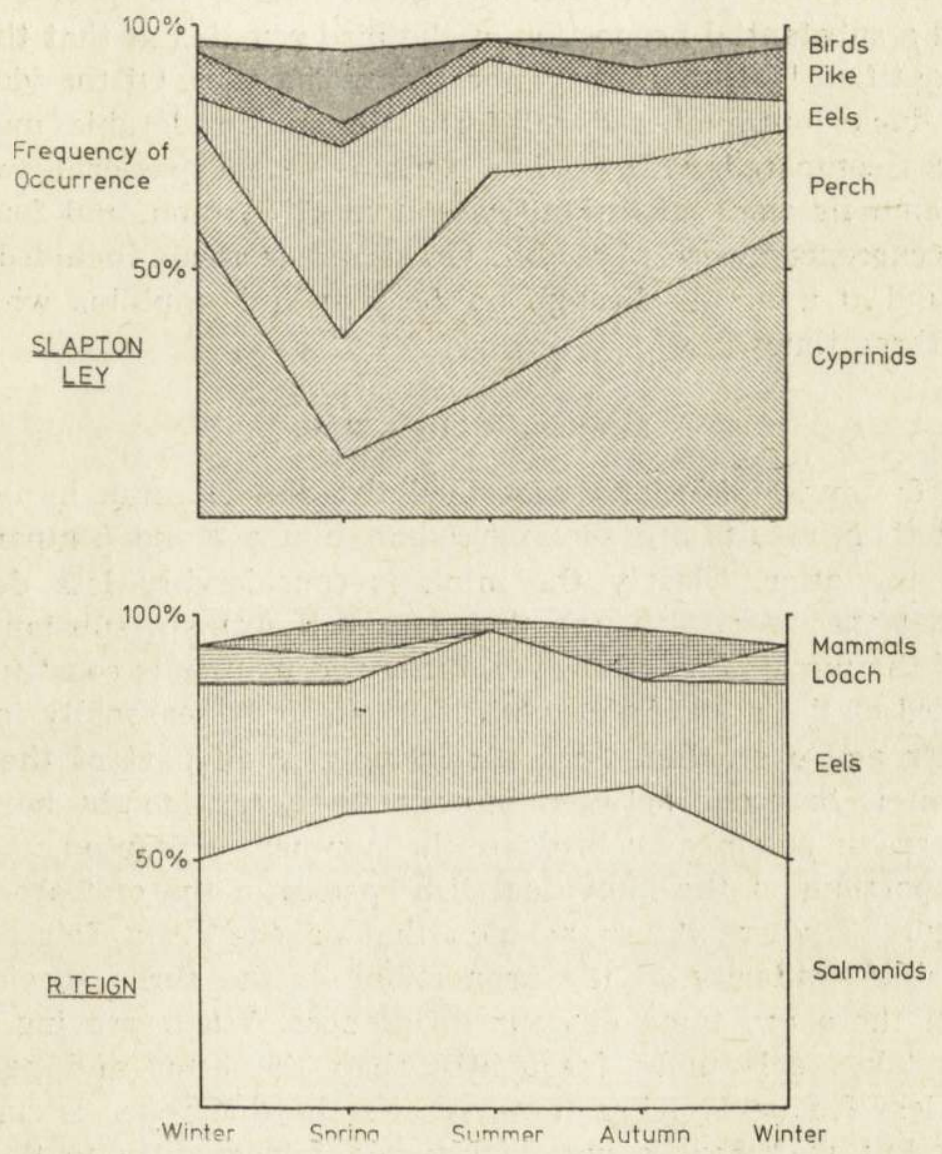

Fig. 1. Seasonal variation in the diet of the otter

most vulnerable as they are slower moving in the colder water. The sudden decrease in the frequency of cyprinids may result partly from their increased mobility as the water temperature rises coupled with the fact that eels are more likely to be encountered at this time as they become active. However, in the warmest months of the year, predation on cyprinids increases again, as well as predation on perch, so other factors may be important. Roach and rudd spawn in May and June in 
shallow water and amongst submerged vegetation and this may decrease their vulnerability to predation. On the other hand, pike are taken most frequently at the time of spawning, forming $17 \%$ of the items recorded at this time (March). Perch fail to fit into a pattern around their spawning time (April and May) being taken in the same proportion as in the previous quarter.

Predation on birds at Slapton is highest during the period April to June, and a substantial proportion of the bird remains at that time could not be identified further as they were from juveniles. Of the identifiable remains, ducks outnumbered ralliforms by a considerable margin (18 occurrences compared with 4). The remains of one passerine were also found. Mammals were an insignificant item at Slapton, and four out of the six occurrences were of rabbit. Other minor items included sticklebacks, found at intervals throughout the year and amphibia which were recorded three times.

\section{Relations with the Mink}

Chanin \& Linn (1980) have described the diet of mink in these two areas and their results are summarised in figure 2 and compared with those for the otter. Clearly the mink is considerably less dependent on fish that the otter, although this item still forms a substantial proportion of the mink's diet. However, birds and mammals constitute more than a third of the mink's diet while they are only seasonally important to the otter and even then form a relatively small part of the diet. If competition is to occur between mink and otter, it might be for fish in either area or possibly for birds, in the summer, at Slapton.

The proportions of the individual fish species in the diet are illustrated in figure 3 where it can be seen that on the river Teign there is a remarkable similarity in the proportions of the three species while at Slapton there are some obvious differences. When preying on fish, the mink takes eels more frequently than the otter and perch and cyprinids less frequently. For these species the difference is significant $(P<0.001)$ but sticklebacks were taken too infrequently to determine. Pike were not found in the mink scats collected. It should be noted that a disproportionate number of mink scats were collected during the summer months when otters also take eels more frequently, but even when allowances are made for this, a similar pattern emerges. Since on the Teign mink are able to catch salmonid fish with considerable success, it seems unlikely that it is their fishing ability which causes the different patterns of predation at Slapton. The most probable reason is a difference in hunting behaviour. Mink tend to hunt by searching from the bank and diving in after a fish has been seen 
(Dunstone, 1976), while otters hunt by diving from the surface and searching under water. The gently shelving shores of the Ley make the mink's normal hunting technique impossible and it must therefore search while in the water. The difference in diets may be due either to the fact that the mink is only able to catch slow-moving fish in this way because it does not have the impetus of its initial dive, or because it cannot stay below water for as long as the otter, or because it
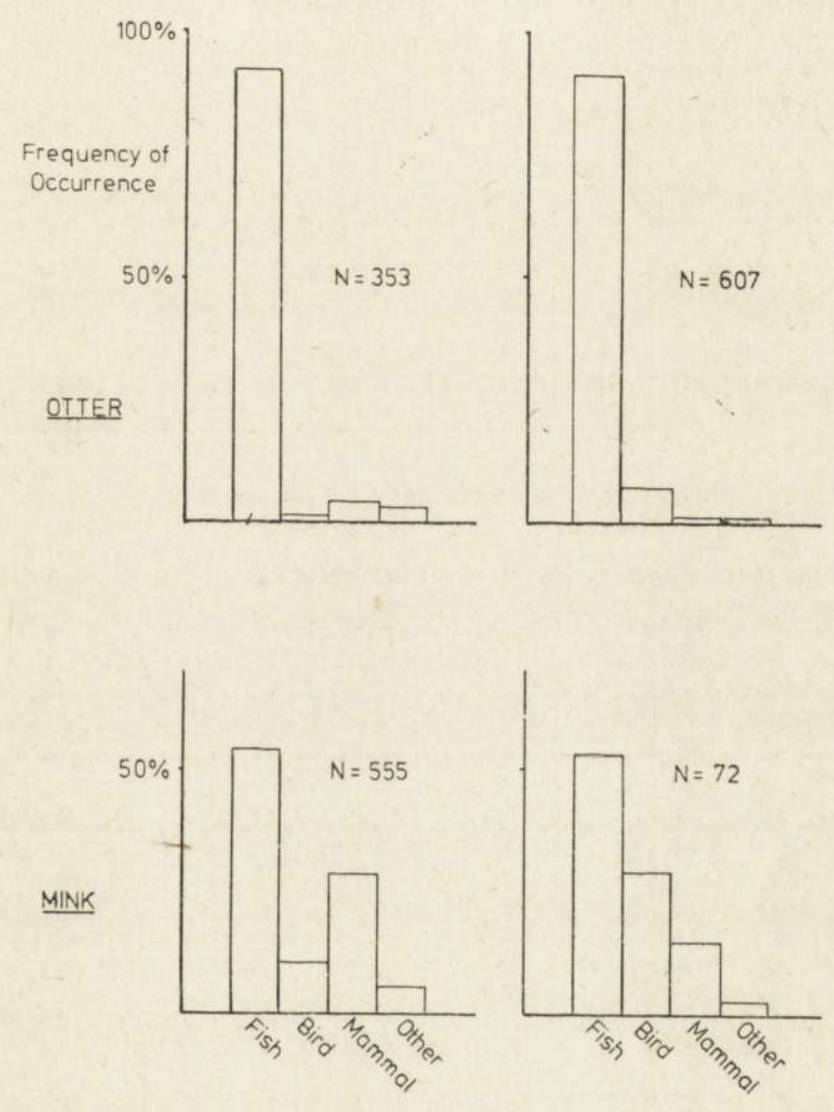

RTEIGN

SLAPTON LEY

Fig. 2. Comparison of the diets of otter and mink on each study area.

hunts in different places. If the mink stayed close to the shore and hunted more in the reeds than in open water, for example, it might be more likely to encounter eels and sticklebacks than perch, cyprinids and pike, so a difference in habitats hunted by mink and otter may account at least in part for the observed differences in fish predation.

There is also a significant difference in predation on birds at Slapton 
$(P<0.01)$. In sixteen mink scats containing identifiable bird remains, even contained the remains of ralliforms and four the remains of ducks. Twenty three otter spraints contained identifiable remains and eighteen of these were ducks and four were ralliforms. The reasons for mink taking mainly ralliforms may be that they are more easily killed by this predator than the much larger ducks, and also that they spend more time in reeds. Ducks roost in open water where they may be more vulnerable to otter predation than mink.
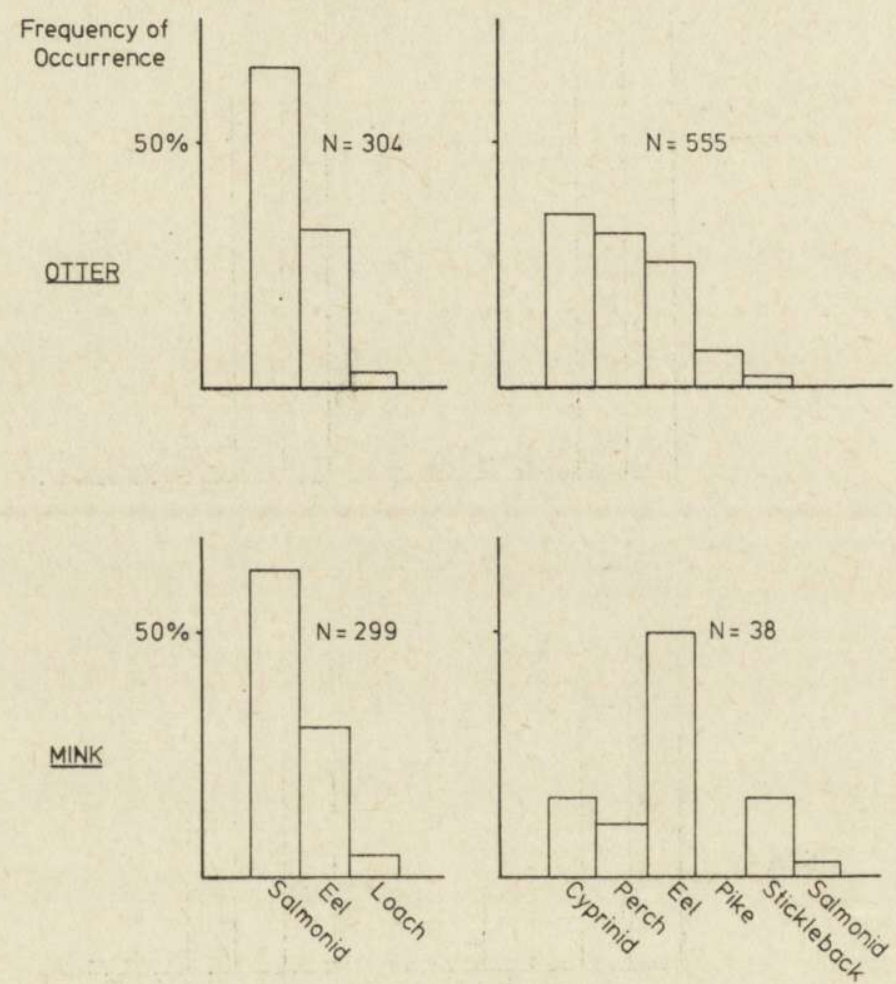

R.TEIGN

SLAPTON LEY

Fig. 3. Comparison of fish predation by mink and otter.

Results expressed as a percentage of the total number of fish remains recordied for each predator on each area.

At Siapton Ley, then, there is a certain amount of separation in the diets of mink and otter and in view of the abundance of wildlife on this study area it would seem that otters and mink are unlikely to compete for food. On the river Teign, the likelihood of competition appears to be much greater since there is much more overlap in the 
diet. As Salmonids form $34 \%$ of the mink's diet and $60 \%$ of the otter's they are very likely to be competed for and although eels were taken less frequently by both species, the fact that they are considered to be small in size and few in number (Bielby, 1964) indicates that there may be competiton for them too. Table 2 illustrates the results of estimating the size of salmonids eaten and shows that if there is selection for different size groups, it is the same for both species of mustelid. In

Table 2

The size frequencies of salmonid fish taken by mink and otter on the river Teign.

\begin{tabular}{lcc}
\hline \multicolumn{1}{c}{ Size of fish } & Mink prey & Otter prey \\
\hline up to $120 \mathrm{~mm}$ & $58 \%$ & $58 \%$ \\
$120-250 \mathrm{~mm}$ & $38 \%$ & $35 \%$ \\
Over $250 \mathrm{~mm}$ & $4 \%$ & $7 \%$ \\
Number of samples & 199 & 285 \\
\hline
\end{tabular}

Table 3

\begin{tabular}{cc}
$\begin{array}{c}\text { Biomass of saimonids in the river Teign and Danish } \\
\text { streams. Values for Teign are estimated from data in } \\
\text { Bielby (1964) and Nott (1973). }\end{array}$ \\
\hline Site & Biomass \\
\hline River Teign 1963 & $6.2 \mathrm{~g} \mathrm{~m}^{-2}$ \\
River Teign 1972 & $5.2 \mathrm{~g} \mathrm{~m}^{-2}$ \\
Study area 1963 & $6.9 \mathrm{~g} \mathrm{~m}^{-2}$ \\
Study area 1972 & $3.2 \mathrm{~g} \mathrm{~m}^{-2}$ \\
Minimum value from Mortensen (1977) & $6.5 \mathrm{~g} \mathrm{~m}^{-2}$ \\
Maximum value from Mortensen (1977) & $23.6 \mathrm{~g} \mathrm{~m}^{-2}$ \\
\hline
\end{tabular}

additior, the abundance of salmonids in the river is not high. Approximate estimates of biomass of salmonids can be derived from the data in Bielby (1964) and Nott (1973) reporting the results of fish surveys in the river. These values are low in comparison with those obtained by Mortensen (1977) for streams in Denmark (Table 3) and the mean value for the sample points within the study area in 1972 is particularly low.

As eels seem to form a relatively small proportion of the total biomass in the Teign (Bielby, 1964) and other species are taken but rarely, it is clear that the main shared food sources on the river are scarce and were particularly so within the study area at the time that spraints were being collected. 


\section{DISCUSSION}

The overall picture of the otter's diet as revealed by these studies is similar to that discovered elsewhere, with fish forming the bulk of the diet, and the different species of fish being taken according to their abundance and availability. It is interesting to note that on the eutrophic lake where three species are common, the otter is able to vary its diet through the year to take advantage of seasonal changes in availability. On the oligotrophic stream, however, where salmonid fish are the only abundant source of food, seasonal variation is much less marked. It is also evident that on the Teign, eels are taken more frequently than one would expect from their relative abundance and this may reflect the fact that eels are more easily caught by otters than the fast-swimming salmonids (Erlinge, 1968).

There are remarkable differences in the patterns of seasonal predation on eels between the two study areas and there are similar differences in the results of other studies. Erlinge (1967) found that in all his study areas otters fed on eels mainly in the warmer months of the year and that in winter, eel remains were rarely encountered. This closely parallels the situation at Slapton Ley. Webb (1975) on the other hand showed that eels were the most important single species in the diet of otters on the Somerset Levels and the there was no variation through the year. In Scotland, Jenkins et al. (1979) also found that eels dominated the diet but they showed that the importance was least in January and February and in July and August. This is almost the complete reverse of the pattern on the river Teign. Since no consistent pattern emerges, it seems likely that seasonal variation in predation on eels may depend partly on changes in the behaviour of the eels, and partly on changes in the hunting behaviour of otters, which may be modified by the availability of other types of prey.

The general pattern of predation on cyprinids revealed by this study and those of Erlinge (1967), Webb (1975) and Wise (1978) are the same, with these fish being eaten most frequently in the winter and least in the summer. Webb attributes this to greater mobility of the fish in summer, Erlinge to changes in shoaling behaviour and distribution within the lakes and Wise to changes in eel availability allied to an increase in cyprinid swimming speed in summer, In the present study it is notable that cyprinids were taken least frequently during the spawning season and then with increasing frequency in the following months.

Erlinge (1967) and Jenkins et al. (1979) found that perch were taken most frequently in the colder months but the reverse was found in this study. The seasonal variation in perch predation observed by Wise was not constant from year to year, predation being least in spring one 
year and winter the next and she noted that otters seemed either to avoid perch or to selectively prey on cyprinids since the ratio of these species in the diet was $4: 1$ whereas in the Ley the disparity in numbers was not so great. Bregazzi (1978) showed that perch had declined in number in Slapton Ley during the period between this study and that of Wise (1978).

The fact that otters have a choice of three species of relatively common fish at Slapton Ley means that declines in the abundance or availability of any one of them may be compensated by an increase in predation on one of the other species. In addition, both pike and ducks contribute significantly to the diet at certain times of the year and might bear an increase in predation pressure if circumstances were to change. On the river Teign, on the other hand, the otter is probably totally dependant on the abundance of salmonids since eels are not sufficiently plentiful to act as a buffer if salmonid numbers are reduced. While mammals are sufficiently abundant to form an alternative source of food, the otter would have to substantially modify its hunting behaviour to successfully exploit them. The otter is therefore much more vulnerable to changes in food supply on the river than on the lake.

\section{Competition}

The diets of mink and otters in these two areas are sufficiently similar for competition to be a possibility, particularly on the Teign. Without detailed studies of numbers and densities of the two species, it is not possible to demonstrate that it happens however.

Studies of the mink populations in these areas have been carried out by Chanin (1976) and Birks (unpubl.). They have found that the mink population of Slapton Ley is lower than might be expected in what appears to be optimal habitat. Some apparently suitable parts of the lake are not always exploited by mink. On the Teign, the home ranges of mink are not stable for long periods, and most resident mink only stay in the area not for a few months. In addition, on this river, mink spend a substantial proportion of their time hunting away from water.

Information on otter densities comes only from casual observations but it would appear that Slapton Ley is heavily used by otters as signs of activity are abundant and otters regularly breed there. Otter spraint is easily collected at Slapton Ley (mean 22 per visit) compared to mink scats (mean: 3 per visit). Erlinge has suggested that, in optimal habitat, otters might keep the mink population low by interference, and this may explain the apparently low numbers of mink at Slapton Ley.

During the course of this study otters appeared to be only casual 
visitors to be Teign (Erlinge, pers. comm.) but they subsequently bred downstream of the study area and were occasionally sighted within it. Owing to the impoverished food supply on this river, it would appear to be sub-optimal habitat for mink and otter and the extent to which competition affected their use of the river cannot be determined.

Acknowledgements: The otter spraints were collected while the author was in receipt of a Natural Environment Research Council research studentship and analysed while he was working under a research fellowship awarded by the World Wildlife Fund. Thanks are due to Ian Linn for advice and for comments on the manuscript.

\section{REFERENCES}

1. Bielby G. H., 1964: River Teign fisheries survey - 1963. Exeter: Devon River Authority.

2. Bregazzi P. R., 1978: The biology and management of perch (Perca fluviatilis) and pike (Esox lucius) in Slapton Ley, Devon. Ph. D. Thesis. University of Exeter.

3. Chanin P. R. F., 1976: The ecology of feral mink (Mustela vison Schreber) in Devon. Ph. D. Thesis. University of Exeter.

4. Chanin P. R. F. \& Linn I. J., 1980: The diet of the feral mink (Mustela vison Schreber) in Southwest Britain. J. Zool., Lond., 192: 205-223.

5. Day M. G., 1966: Identification of hair and feather remains in the gut and faeces of stoats and weasels. J. Zool., Lond., 148: 201-217.

6. Dunstone N., 1976: Vision in relation to sub-aquatic predatory behaviour in the mink (Mustela vison Schreber). Ph. D. Thesis. University College of Wales, Aberystwyth.

7. Erlinge S., 1967: Food habits of the fish-otter (Lutra lutra L.) in south Swedish habitats. Viltrevy, 4: $371-443$.

8. Erlinge S., 1968: Food studies on captive otters (Lutra lutra), Oikos, 19; $259-270$.

9. Erlinge S., 1969: Food habits of the otter (Lutra lutra) and the mink (Mustela vison) in a trout water in southern Sweden. Oikos, 20: 1-7.

10. Erlinge S., 1972: Interspecific relations between otter (Lutra lutra) and mink (Mustela vison). Oikos, 23: 327-335.

11. Harris C, J., 1968: A study of the recent Lutrinae. London: Wiedenfeld \& Nicholson.

12. Jenkins D., Walker J. G. K., \& McCowan D., 1979: Analyses of otter (Lutra lutra) faeces from Deeside, N. E. Scotland. J. Zool., Lond., 187: 235-244.

13. Lockie J. D., 1959: The estimation of the food of foxes. J. Wildl. Mgmt., 23: $224-227$.

14. Mortensen E., 1977: Fish production in small Danish streams. Folia Limnologica Scandinavia, 17: 21-26.

15. Nott F. J., 1973: River Teign fisheries survey-1972. Exeter: Devon River Authority.

16. Perrett R., 1958: Eels. How to catch them. Frome: Hillman \& Sons.

17. Stephens M. N., 1957: The otter report. London: Universities Federation for Animal Welfare. 
18. Webb J. B., 1975: Food of the otter (Lutra lutra) on the Somerset levels. J. Zool., Lond., 177: 486-491.

19. Wise M. H., 1978: The feeding ecology of otters and mink in Devon. Ph. D. Thesis. University of Exeter.

Accepted, September 20, 1980.

\section{Paul CHANIN}

\section{POKARM WYDRY W POEUDNIOWEJ ANGLII}

\section{Streszczenie}

Kal wydry był zbierany w dwu regionach południowej Anglii: w okolicach Slapton Ley - eutroficznego jeziora i wzdłuż $12 \mathrm{~km}$ odcinka Teign - oligotroficznej rzeki.

Ponad $90 \%$ pokarmu zidentyfikowanego w kale stanowiły ryby (Tabela 1). W rzece łososiowate występowały dwa razy częściej niż węgorze, i w takiej proporcji spotykano je w kale. W jeziorze karpiowate, węgorze i okonie jedzone były najczęściej, chociaż a szczupaki tworzyly istotną część diety. Szczątki ptaków i ssaków występowały w niewielkiej liczbie prób kałowych w obu areałach.

Proporcje głównych gatunków ryb zmieniają się w ciągu roku, szczególnie w Slapton Lay (Ryc. 1) i niektóre $\mathrm{z}$ tych zmian mogą być łączone ze zmianami w aktywności i behawiorze ryb. Chociaż ryby stanowią mniej niż połowę diety norki amerykańskiej występuje znaczne zachodzenie na siebie diet norki i wydry (Ryc. 2). Dane ze Slapton Ley świadczą o zróżnicowanym sposobie polowania norki (Ryc. 1) i to razem z obfitością pokarmu w terenie czyni współzawodnictwo o pokarm nieprawdopodobne. Na rzece Teign jedna norka i wydra pobierają różne gatunki i różne wielkości ryb $w$ tych samych proporcjach (Tabela 2). Biomasa ryb w tej rzece wydaje się być niska (Tabela 3) i konkurencja nie może być wykluiczona. 